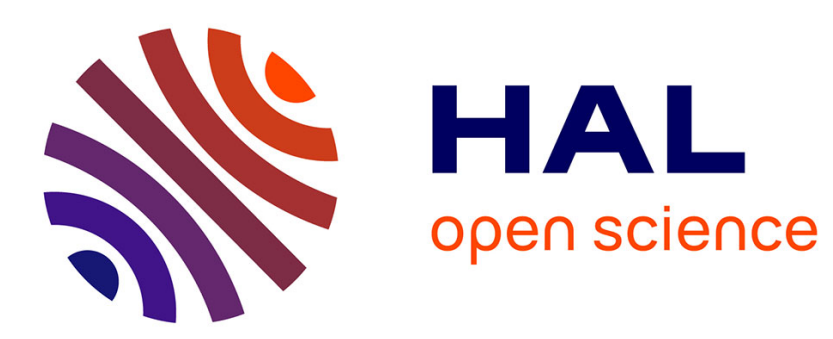

\title{
Is there a first mover advantage in science? Pioneering behavior and scientific production in nanotechnology
}

\author{
Mareva Sabatier, Barthelemy Chollet
}

\section{To cite this version:}

Mareva Sabatier, Barthelemy Chollet. Is there a first mover advantage in science? Pioneering behavior and scientific production in nanotechnology. Research Policy, 2017, 46, pp.522 - 533. 10.1016/j.respol.2017.01.003 . hal-01522764

HAL Id: hal-01522764

https://hal.science/hal-01522764

Submitted on 15 May 2017

HAL is a multi-disciplinary open access archive for the deposit and dissemination of scientific research documents, whether they are published or not. The documents may come from teaching and research institutions in France or abroad, or from public or private research centers.
L'archive ouverte pluridisciplinaire $\mathbf{H A L}$, est destinée au dépôt et à la diffusion de documents scientifiques de niveau recherche, publiés ou non, émanant des établissements d'enseignement et de recherche français ou étrangers, des laboratoires publics ou privés. 


\title{
Is there a first mover advantage in Science? \\ Pioneering behavior and scientific production in nanotechnology
}

\author{
Mareva Sabatier* \\ IREGE, Université Savoie Mont Blanc \\ Barthélemy Chollet \\ Grenoble Ecole de Management - IREGE, Université Savoie Mont Blanc
}

*corresponding author:

BP 80439 - 74944 Annecy-le-Vieux Cedex - FRANCE

Phone: 00-33-(0)4-50-09-24-59

e-mail: mareva.sabatier@univ-smb.fr

\begin{abstract}
:
This article investigates whether pioneers in a research field have a sustainable first mover advantage in publications. Combining bibliometric (publications, citations, co-authorship) with survey data on 495 nanotechnology researchers, we analyzed career attributes, professional context and production overtime. Our econometric estimates highlight two main results. First, pioneering behavior is not exogenous: it is more probable among scientists who are already established in their "mother-discipline" (before entering nanotechnology), have a strong collaboration network, and have easy access to field-specific resources. Second, even after controlling for the endogeneity of entry timing, we find a strong first mover advantage: pioneers in the emerging field exhibit significantly higher scientific production in that field in the long run.
\end{abstract}

JEL Codes: 030, L31, C31

Keywords: first mover advantage, scientific production, pioneering behavior, nanotechnology 


\section{Introduction}

A key feature of the sciences is their constant evolution (Bonaccorsi, 2008). Scientific fields emerge and evolve as a function of new discoveries, which yield new questions. Similarly, the appearance of ground breaking technologies opens new possibilities for solving unanswered scientific puzzles, leading to new categories in Science. The disparity in their emergence processes notwithstanding, new fields always confront scientists with fundamental dilemmas about their research trail and career (Debackere and Rappa, 1994): should they invest time and energy in this emerging field? Should they act as pioneers? Or should they wait and see? What are the long term consequences of such a decision?

The notion that some scientists take a pioneering role is inherent to Kuhn's (1962) description of scientific revolutions. Pioneers contribute to the adoption of a new paradigm, involving new "beliefs, values and techniques, shared by the members of a given community" (Kuhn, 1970). Even in approaches more evolutionary than Kuhn's, pioneering works are thought to produce major changes in how scientific problems are solved (Laudan, 1977). They have an impact in the long run on how an emerging field is structured. However, as high as their impact may be at the collective level, it isn't clear yet whether the pioneers get any individual benefit from their early entrance. Although the first articles published in a given topic tend to be much more cited (Price, 1965; Newman, 2009), occasionally some "sleeping beauties" gain impact only long after their publication (Van Raan, 2004). More importantly, that an early paper gets more cited than later ones does not inform whether its author gets an advantage in terms of subsequent production in the field.

This question of entry timing is surprisingly absent from the burgeoning research exploring the factors of individual scientific productivity. The latter includes a wide range of factors from age (Bonaccorsi and Daraio, 2003; Diamond, 1986; Stephan and Levin, 1997), to gender (Hunter and Leahey, 2010), to institutional affiliations (Stephan 1996), to collaboration strategies (Jonkers and Cruz-Castro, 2013; Pezzoni et al., 2012) or international mobility (Jonkers and Cruz-Castro, 2013) to cite just a few. Performance in these cases is analyzed within the scope of a community which is considered as a given, one piece of a larger scientific nomenclature assumed to be stable for the study, therefore making entry timing a non-issue. Perhaps an important explanation for this gap is that this array of factors influences not only a scientist's productivity, but also entry timing itself. That is, pioneering behavior needs to be considered as partly endogenous (Lieberman and Montgomery, 1988). Support for this notion is provided by Debackere and Rappa's $(1993,1994)$ studies comparing early entrants in a scientific field with their followers. They found that early entrants indeed have specific profiles. Thus, the question of what is the reward of pioneering behaviors (i.e. is there a first mover advantage) is tightly coupled to another one: what drives such behaviors (i.e. who are the first-movers)?

Both questions have important implications for research policy. They entail specific scientific strategies for laboratories, in terms of recruitment and incentives to encourage (or discourage) pioneering behaviors. Through the identification of the typical profile of early entrants in a field, policy makers can be informed on the type of researchers they need to enable in order to promote knowledge breakthrough. At an individual level, it sheds light on how researchers need to strategize about entry timing. 
Our objective in this paper is two-fold. First, it is to test whether first-movers do have an advantage in terms of further scientific production in an emerging field. Second, it is to investigate what specific characteristics increase the chances that a scientist engages in it. For this double purpose we rely on the extended literature in marketing and strategic management discussing first mover advantages and disadvantages (Kerin et al., 1992; Gomez-Villanueva et al., 2013; Lieberman and Montgomery, 1988; Suarez and Lanzolla, 2007). We translate these debates to the context of scientific publication and test their applicability to the case of nanotechnology, which emerged in the mid-1990s and strongly appealed to scientists from a variety of disciplines, from physics to life science. We exploit a rich data set that combines bibliometric data (dates of publication, publication counts, citation counts, co-authorship relationships) and a survey on the scientific careers and professional context of French nanotechnology researchers. This dataset allows estimating the effect of pioneering behavior on future scientific production, accounting meanwhile for the potential endogeneity of entry timing.

We structure the remainder of this article as follows. Section 2 sets out theoretical foundations for first mover advantages and disadvantages in Science, particularly nanotechnology. Section 3 describes the data and methods. Section 4 presents the econometric results. Section 5 concludes with a discussion of the results and suggestions for further research.

\section{Antecedents and outcomes of entry timing in an emerging field}

\subsection{Outcomes: first mover advantages and disadvantages}

\subsubsection{First mover advantages}

Pioneering behavior has received a lot of attention in the field of firm competitive strategies, resulting in arguments in support for both first mover advantage and disadvantage. Perhaps the most intuitive argument for first mover advantage is that the advance of early entrants ensures technical leadership and creates a technology gap that competitors might never bridge. As they develop knowledge in new research processes and techniques (Kerin et al., 1992), pioneers can maintain this advantage overtime. In the field studied in this paper, nanotechnology research, this argument is made even stronger by the prevailing role infrastructures played in its development. Consistent with Darby and Zucker's (2005) demonstration that research in nanotechnology consists in the "invention of a method of invention" in Griliches' sense (1957), pioneers had to adapt and develop new equipment tailored for the nanoscale. They could capitalize on this experience and gain considerable timing advantage in developing applied research in that field. For example, the history of the scanning tunneling microscope shows that early users were heavily involved in its development and modified it to better match their needs (Mody, 2011). In this example, early exposure to this technology probably provided an advantage for further research.

Another advantage of pioneering behavior is reputational (Lilien and Yoon, 1990). This mechanism is particularly relevant in scientific research, where reputation has a considerable effect on scientists' ability to attract new co-authors and funding (Newman, 2009), resulting in a self-reinforcing dynamic of success known as the Matthew effect 
(Merton, 1968). High status researchers get better research conditions (in terms of funding, teaching and administrative tasks), therefore enjoying higher chances to be productive and visible in the community (Stephan, 1996). As first movers enter an empty field, it is theoretically easier for their work to gain visibility and serve as a landmark for future entrants (Newman, 2009). With this prominent position they can pre-empt scarce resources (Boulding and Christen, 2008). The latter can be human: early movers can establish international collaborations networks which will be more difficult to join thereafter. Of course there are also financial resources to be preempted. In nanotechnology research, in particular, the dramatic increase in government funding took place around 2000 (i.e. launch of the US National Nano Initiative in 2001, nanotechnology named as a priority in the Sixth Framework Program in 2002 (Palmberg et al., 2009)). Building on their legitimacy, nanotechnology researchers who were already established and had a publication track in the field were in a better position to address those calls, if not to simply take part in their conception and execution as subject-matter experts.

\subsubsection{First mover disadvantages}

Pioneering behavior, on the other hand, might as well have disadvantages, such as pioneering inflexibility - that is, the inability to change due to investments in fixed assets and switching costs (Lieberman and Montgomery, 1988). For example, nanotechnology research required costly infrastructures, which must have prolonged use to justify costs. This important initial investment may limit the possibility of discovering new fields in the future and quickly adapting to prescribers' needs (e.g., industrial specifications). Later entrants, on the contrary, tend to face lower entry barriers. For example, if in the early years of the scanning tunneling microscope its cost was extremely high, microscopy became cheaper overtime and even small labs came to be able to afford it. Similarly, whereas material characterization would initially systematically need important equipment, research progress opened possibilities to use much cheaper methods such as computer simulation.

Another typical disadvantage relates to free-riding behaviors, whereby followers benefit from the efforts of early entrants (Jensen, 2003). Researchers have an incentive to wait and see, as pioneering work may provide them with valuable knowledge on equipment and research processes, while not partaking in the cost of its development. Especially if returns are uncertain, as is often the case during discovery phases, exploiting the pioneer's experience can be advantageous for followers. In "regular" economic sectors, such freeriding is usually mitigated by first-movers' attempts to erect barriers to imitation (Gal-Or, $1985,1987)$, such as patenting. Patents limit competition for a while, during which the firm can consolidate a market position and gain advance down the learning curve. However, in the publication arena, there is scarcely any tool to increase the cost of imitation for later entrants. On the contrary, a large part of the research activity is to disseminate to the scientific community through conferences, workshops and seminars (Stephan, 1996), in order to gain visibility. In nanotechnology, moreover, there has been a clear division of labor, whereby an early mover would typically contribute by shedding light on a new material, and as a result open great research prospects for second movers who would focus on the characterization or method of production of that material.

Last, first movers in Science may suffer from resistance to change similar to what is observed among customers facing a new product (Carpenter and Nakamoto, 1989). In the publication 
arena, where customers, so to speak, are journal referees and editors, pioneers face major obstacles inherent to the peer review process (Lee et al., 2013). Due to conservatism biases, ground-breaking research is more difficult to publish (Braben, 2004; Gans and Shepherd, 1994). As they lack a frame of reference, referees are more likely to perceive very novel research as less rigorous or solid than more conventional research. In a qualitative study of the European Research Council's projets, Luukkonen (2012) found that referees tend to qualify frontier research with terms such as "paradigm-shifting" and "revolutionary" but reserve terms such as "excellent" for "methodologically rigorous" works that contribute to more established fields. Such context provides a bonus to followers, who face lower bias once the field is more established. Note that such bias is even stronger if the emerging field relies on the crossing of pre-existing established fields, which was the case of nanotechnology research (Avenel et al., 2007; Rocco and Bainbridge, 2002). In spite of the value of interdisciplinary works to address new problems (Metzger and Zare, 1999), they receive lower ratings in peer review processes (Porter and Rossini, 1985), mainly because scientific journals are often focused on one discipline and recruit referees who, as field experts, may not have the skills to assess the contribution of multidisciplinary work, increasing the rejection likelihood. Once a field is better established, specialty journals emerge, opening new outlets for publications. In 1990 was created the first journal claiming explicitly a positioning on nanotechnology, and several creations followed, especially from the late nineties (Schummer, 2004). For example, in the Science Citation Index, three journals contained the root "nano" in 2003, six in 2004 and twelve in 2005 (Leydesdorff, 2008). Early entrants obviously had to deal with a more limited number of outlets than later movers.

\subsection{Antecedents: Field entry timing as an endogenous variable}

\subsubsection{Applying the question of entry timing to the context of scientific publication}

A traditional view of first mover advantage theory discusses entry timing as exogenous, i.e. a purely deliberate decision accessible to any economic actor in a competitive field. Lieberman and Montgomery (1988) suggested however that entry timing isn't equally valued by actors of a competitive field. In particular, not all actors face similar entry costs and skills (Moore, et al., 1991). As a result, testing for the benefits of pioneering behavior without controlling for the very factors which determine its success might lead to potential bias. The risk is to conclude that entry timing alone drives performance, and that therefore virtually all firms should try to enter early (or late), whereas in facts only some having specific characteristics should. In response to these concerns, a tiny stream of studies has explored the factors conducting to pioneering behaviors, concluding in favor of a mixture of environmental conditions and firm-level capabilities (Garcia-Villaverde et al., 2012; Lee, 2008; Moore et al., 1991).

Applied to Science, the question of entry timing decisions can be seen as a particular case of the larger question of how scientists select their research problems. Although extended research exists on this issue (Zuckerman, 1978), little is known on why some scientists target emerging research problems rather than established ones. A notable exception is a series of studies by Debackere and Rappa $(1993,1994)$ on the factors of entry timing in the field of 
neural networks. They distinguished between cognitive motivations (i.e. the inherent intellectual appeal of a research problem) and social motivations (i.e. the opinion of leading researchers; the potential for peer recognition) and found early entrants to be typically less influenced by social motivations compared with late entrants. They enter the field with less concern for the social acceptance of their choice. An interpretation of these findings points to the role of perceived risk. Contrary to what happens in "regular" economic sectors, the main risk of entering a scientific field is indeed that only few other competitors/peers enter the same field thereafter, preventing it from reaching legitimacy and ultimately resulting in scarce funding as well as limited potential for publication.

Although the literature is scarce, in the following sections we highlight three types of variables which should influence entry timing of researchers.

\subsubsection{Scientific legitimacy}

One important feature determining scientists' pioneering behavior should be their visibility and production records in established fields. Although the reward of entering an emerging field is by nature uncertain, scientists occupying prominent rather than marginal positions in established fields should face lower probability of failing, because their status will facilitate gaining visibility and acceptance. According to status theory, "increasing uncertainty about underlying quality makes perceptions of the quality of the actor's endeavors depend on its status" (Podolny et al., 1996, p.668), a notion that received empirical support in a variety of social and economic areas (Kim and King 2014; Kim 2012; Higgins et al., 2011). As the novelty of methods, theories or concepts involved in early nanotechnology research create uncertainty on research quality, scientists' status serves as a quality signal. Thus, the conservatism biases described in section 2.1.2 should be mitigated for prominent scientists, resulting in higher chances for them to enter the field early.

Supportive empirical evidence to this argument can be found in Azoulay et al. (2013)'s work on the citation boost following the winning of a high-prestige prize. They found that, while the increase in status provides a significant but small and limited citation premium in general, the latter is significantly higher among scientists conducting research in novel areas (as assessed through the vintage of keywords tagging their articles), because quality is then more difficult to evaluate.

\subsubsection{Collaboration networks}

Similar argument can be made for scientists that are highly central in collaboration networks. Establishing a new field requires building networks of collaborations, which empirical evidence suggests to consist mainly in restructuring pre-existing networks, rather than creating them from scratch (Perry and Rice, 1998). In this context, highly central scientists should see more feasibility in pioneering behavior than poorly connected scientists. As they collaborate with many researchers and bring important contributions to them, they can more easily recruit new participants to the emerging field, ultimately increasing their chances of success. Consequently, we expect scientists who are already highly connected in established fields to have higher chances to enter an emerging field early.

Size however is not the only meaningful feature of collaboration networks. Structure also matters. Researchers with a sparse collaboration network (co-authors who themselves do not collaborate together) are often pictured as ideally positioned to broker knowledge and 
benefit from it (McFadyen et al., 2009). On the other hand, denser networks are of great value when a focal individual's point is to engage is some collective action, which requires cohesion, mutual understanding and trust (Burt, 2005). Density entails frequent and redundant information sharing, which eventually favors the development of collaboration norms and habits, as well as mutual awareness (Reagans and McEvily 2003). This kind of highly cohesive collaboration network should be an asset to heighten the chances of success when entering an emerging field.

\subsubsection{Access to field-specific resources}

Another factor that should determine pioneering behaviors relates to the amount of resources required to enter a new field. The experience effect claimed in support of the first mover advantage occurs only if early entrants are able to move down the experience curve fast enough (Franco et al., 2009). This requires holding sufficient knowledge and technological resources, without which the timing advantage is of no particular value. This phenomenon is particularly salient in the case of nanotechnology, which developed thanks to technological platforms. Their access was literally a precondition to design and conduct most projects in the field. Moreover, attached to those platforms was rich tacit knowledge, often inherited from a long history of local research, supported by multi-institutional consortia (Robinson et al., 2007). Embeddedness in such clusters was therefore a strong facilitator for researchers, due to knowledge stickiness (Bozeman et al., 2007). Thus, we expect proximity to those clusters to increase the odds of engaging in pioneering behavior. While such proximity can obviously stem from an affiliation to one of the institutions or companies involved in one of those prominent clusters, social ties may as well achieve this outcome. Collaboration ties are indeed contexts where some focal scientist can indirectly access the resources of others (Laudel, 2002). Collaborators who are already established in the field can offer a "shortcut" to field-specific resources, therefore having such type of tie should facilitate field entry.

All in all, if scientists vary in their probability to be pioneers as a function of their professional characteristics, the latter must be controlled for when testing the impact of entry timing. That is what we do hereafter, using French data on nanotechnology research.

\section{Data and method}

\subsection{Focus on the French context}

To test for the first mover advantage hypothesis, we decided to focus on the emergence of nanotechnology. As a field carrying promises of broad and profound implications for many industries, such as advanced materials, biotechnology and pharmaceuticals, electronics, scientific tools and industrial manufacturing processes, early nanotechnology research appealed to scientists from a variety of established disciplines, from physics to biology to chemistry. We decided to limit our focus on one country, France.

The first motivation for this focus relates to the relevant scope of competition to be considered in such a context. To be sure, scientists around the globe have similar scientific standards, compete for publication space in the same outlets and participate in the same knowledge communities. With this respect, one could consider the entire world as the 
natural scope for studying pioneering behaviors. However, a closer consideration of national research systems and, within them, how individuals strategize about their career, leads to a different view. Intense competition also takes place at a national level, for two reasons: funding and institutional frameworks. Public funding plaid a considerable role in the rise of scientific production in nanotechnology (Beaudry and Allaoui, 2012; Zucker et al., 2007) and obviously it was primarily spread by governments among researchers of the same nation (Wang and Shapira, 2011). French scientists had to compete primarily with their French colleagues for funding as well as access to platforms.

As per institutional frameworks, the French national research system has been described as extremely centralized and discipline-dominated (Clark, 1993). These peculiarities also induce scientists to reason and strategize at a national level. For example, in universities, both recruitments and access to professorial positions are conditioned by the validation of an elected committee of peers, the Conseil National des Universités (Pezzoni et al., 2012) who, within a discipline, are responsible for screening all applicants. Obviously, each profile is assessed against standards which depend heavily on the average performance of the national population of researchers in the field, rather than rigid international standards. Even once a position is reached, rank advancement is also affected by such committees, and the French Research Ministry sanctions all promotions which are obviously in limited supply.

The second motivation for focusing on one country was to set aside international heterogeneity. Due to tremendous discrepancies in terms of institutional context, knowledge base and resources availability, there are reasons to think that the ability to translate earliness into an advantage as well as the factors affecting entry timing are specific to a country. To cite just one example, the control of disciplines on promotions and funding programs might raise strong barriers to pioneering behaviors in France compared with a similar behavior in the U.S.A., where there is much more flexibility (Whitley, 2003). Thus, if theoretically a global analysis of all nanotechnology publications worldwide would be possible through bibliometric analysis, it would not allow accounting properly for endogeneity.

\subsection{Delineation of a population of active researchers in nanotechnology}

We constructed an original data set matching bibliometric data on scientific production, coauthorship relationships and citations, with survey-based data on individual and career characteristics for a sample of French scientists active in the nanotechnology field. In 2013 we identified all publications of researchers belonging to a French institution on the ISI Web of Science that were published in scientific journals between 1998 and 2006 and fell into the nanotechnology category, as defined by Mogoutov and Kahane (2007). Among them, we isolated all active researchers, which we defined as those who published more than 5 papers during that period ${ }^{1}$.

\footnotetext{
${ }^{1}$ In other words, our study concentrates on the $10 \%$ most productive researcher in the field. A larger query of all publications in nanotechnology in France was also completed to estimate the specificities of this subset and showed that they clearly tend to have been earlier on average to enter the field than the $90 \%$ least active scientists (average year of entry 1994.67 versus 2000.03). Therefore, our data set clearly underrepresents later entrants, who happen to be among the least active researchers. Thus, our sample selection could lead to underestimation of the first mover advantage and our econometric results should be interpreted with caution.
} 
Such is the difficulty of delineating nanotechnology that it has become a research area in itself (Arora et al., 2013). Most methods rely on algorithms that isolate publications by searching for relevant keywords associated with nanotechnology within titles, keywords, and abstracts. Their salient differences lie in how they define the list of keywords, and most importantly the role they grant to field experts in the process. Mogoutov and Kahane's method relies on an initial query based on keywords, resulting in a set of "core publications". It departs from purely lexical methods in its next step, as it draws semi-automatically new keywords from those core publications, and relies on experts for validation of the list only then so as to minimize biases (Mogoutov and Kahane, 2007). A recent comparison of six methods (Huang et al., 2011) placed Mogoutov and Kahane's approach as yielding the largest corpus of publications. This feature made it particularly suited for our research goal: as we focus on individual entry in the field, particularly focusing on its "earliness" relative to other researchers, priority must be put on getting a valid date of first publication and therefore minimizing the risk of ignoring one particular publication. Huang et al.'s analyses provided further support for this choice, by showing that the specific publications which are detected by Mogoutov and Kahane's method only (i.e. by none of the other methods), lead to similar conclusions in terms of defining the top 10 journals, countries and institutions in nanotechnology.

We selected the 1998-2006 time window because we thought it would include researchers active before - as well as others active only after - the acceleration in public funding observed in the 2000 decade (for instance, the total spending of Japan, USA and France in 2008 was nearly six times higher than that of 2000 (Badillo, 2012)). Also, establishing 1998 as the lower bound would logically permit capturing researchers involved in the steady stream of research progress observed in the nineties (Li et al., 2008). This argument however holds only if we assume they kept some activity after 1998.

On figure 1, dots represent publications and are organized by rows representing their author. A risk associated to our approach was to exclude from our data pioneers who have not succeeded and thus, who were not detected in the 1998-2006 period. This would be the case of scientists $A$ and $B$ in figure 1: 6 papers published in total, but less than 6 if only the 1998-2006 period is considered. To evaluate this bias, we identified all researchers who had published before 1991 (below this threshold lie what we defined as either first mover or second mover in our descriptive analyses - see section 3.3) and which are not observed in our database. We found only 21 researchers. Using a search through internet (via Google Scholar), we collected CV for 16 of these researchers. For 13 of them, we found that they had retired before 2000. Thus, our data collection procedure does not seem to have excluded the pioneers who have failed but rather the pioneers who were nearing retirement in 1998.

Moreover, when comparing the total population of active researchers with those considered active between 1998 and 2006, they don't seem to differ importantly at least in terms of average number of publications in nanotechnology (respectively 48.07 and 47.18 ) and of average date of first publication in nanotechnology (respectively 1994.05 and 1994.51). 
Figure 1: Visual representation of our study population

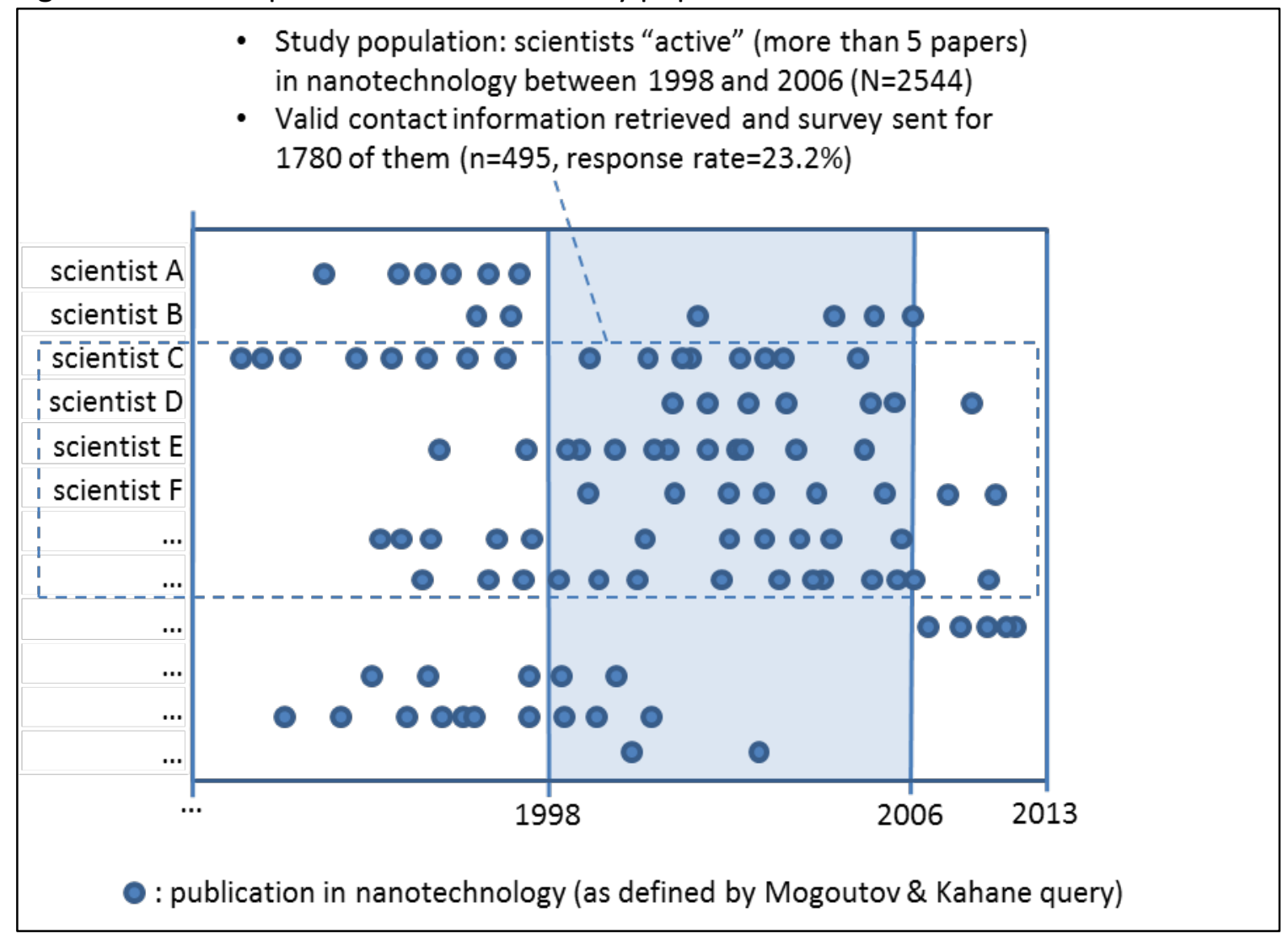

Among the 2,544 researchers identified as active during the 1998-2006 period (dashed box on figure 1), we retrieved e-mail contacts through online searches for only 2,130 researchers, 1,780 of which proved to be valid. We collected 679 questionnaires (response rate $=31.9 \%)$, of which $495(23.2 \%)$ were complete and included in the study ${ }^{2}$. We then identified all nanotechnology publications of those 495 researchers (above and beyond the 1998-2013 window), using the Mogoutov and Kahane (2007) query again. Doing so allowed us to identify the date of their first nanotechnology publication. Moreover, for each publication, we collected information on their co-authors and the number of citations until 2013.

\subsection{Variables}

Using publication data, we built two alternative measures of scientific production in nanotechnology: (1) the number of nanotechnology publications and (2) the number of citations cumulated across all nanotechnology publications.

We also identified for each researcher any publication outside nanotechnology before the date of the first publication in nanotechnology. This allowed us to account for the scientific legitimacy of the scientist (as argued in section 2.2.2). The same database of publications

\footnotetext{
2 To assess response bias we checked for differences between respondents and non-respondents on two variables: date of first publication in nanotechnology (1994.51 for the study population, 1994.67 for our sample) and total number of papers published in that field (47.18 and 47.33 respectively). The differences were not statistically significant.
} 


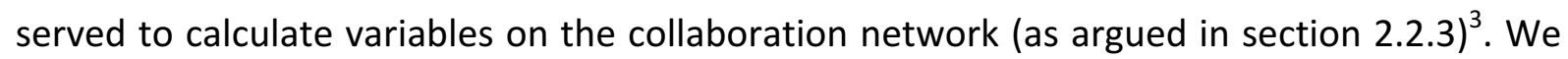
measured a count of all coauthors prior to the field entry (also referred to as degree centrality in network analysis parlance). We calculated ego-network density, which is the number of co-authorship relationships among the co-authors of a focal scientist, divided by the maximal number logically possible of co-authorship relationships (e.g. if A collaborates with both $B, C$ and $D$, but only $B$ and $C$ are themselves co-authors, then the density of $A^{\prime} s$ network is $1 / 3=33,3 \%$, with 3 the number of ties if $B, C$ and $D$ all had a relationship).

The measure of access to field-specific resources (argued in section 2.2.4) was made possible by an analysis of the first publication in nanotechnology of our 495 scientists in the sample. In particular, scientists working in Paris Sud, Grenoble, Toulouse, Lille or Besançon were theoretically in a better position to engage in nanotechnology, as those sites were singled out by the French Research Ministry as holding outstanding material characterization instruments and nanofabrication platforms, and were involved in the National Committee for Scientific Research (CNRS) efforts to improve collaboration and resource sharing among scientists (Badillo, 2012). For each of the 495 scientists in the sample, we checked the affiliation at the time of the first publication in nanotechnology. We created a variable taking 1 if the researcher's affiliation mentioned a location in either one of those five major sites, 0 else. We also created a variable capturing whether the target author's affiliation at that time was out of France. In most cases, such affiliation was in the USA, where greater technical resources and funding supposedly facilitated field entry. Last, we traced back the year of entry of all co-authors mentioned on the very first publication, and created a count of all coauthors who were already in nanotechnology at that time, consistent with our argument that prior socialization with nanotechnology scientists also increased the chances of entry (section 2.2.4).

We complemented these bibliometric data with questionnaire responses eliciting information on respondents' educational background and current and prior professional positions. Respondents identified their current affiliation and up to two prior affiliations from an exhaustive list of French universities and research labs and broader categories for positions outside France or in the business sector. Respondents also noted their year-byyear professional status since the completion of their doctoral degree and detailed responsibilities as a principal investigator in various types of grants for the 10 years preceding the survey. We collected information on respondents' main disciplinary field from a list of 14 areas defined by the French Ministry of Research. Following data collection, we collapsed these areas into five main disciplines: Physics, Biology, Mechatronics, Earth Science and Chemistry.

We also controlled for scientists' type of institutional affiliation. We distinguished between affiliations to public (universities, government research agencies) versus private institutions. Our data, however, does not identify longitudinally all the characteristics of scientists' organizations, such as size, composition, etc. This caveat is due to intense institutional agglomerations or name changes over time, which makes it difficult to track laboratories' attributes longitudinally.

\footnotetext{
${ }^{3}$ When publications had more than 15 authors, though, only the 15 first authors were considered to infer network measures (only $1 \%$ of all publications retrieved in nanotechnology are in this case).
} 
Table 1: Production characteristics in nanotechnology, demographics and educational background by entry rank $(\mathrm{N}=495)$

\begin{tabular}{|c|c|c|c|c|c|c|c|c|c|c|}
\hline \multirow[b]{2}{*}{ Variable } & \multicolumn{2}{|c|}{ All sample } & \multicolumn{2}{|c|}{ First movers } & \multicolumn{2}{|c|}{ Second movers } & \multicolumn{2}{|c|}{ Third movers } & \multicolumn{2}{|c|}{ Last movers } \\
\hline & Mean & $\begin{array}{l}\text { Std. } \\
\text { Dev. }\end{array}$ & Mean & $\begin{array}{l}\text { Std. } \\
\text { Dev. }\end{array}$ & Mean & $\begin{array}{l}\text { Std. } \\
\text { Dev. }\end{array}$ & Mean & $\begin{array}{l}\text { Std. } \\
\text { Dev. }\end{array}$ & Mean & $\begin{array}{l}\text { Std. } \\
\text { Dev. }\end{array}$ \\
\hline Number of publications in nano & 47.33 & 35.33 & 76.27 & 66.07 & 66.11 & 41.42 & 42.66 & 25.07 & 30.66 & 22.24 \\
\hline $\begin{array}{l}\text { Number of publications time } \\
\text { weighted (in logs) in nano }\end{array}$ & 0.76 & 0.71 & 0.69 & 0.66 & 0.81 & 0.71 & 0.76 & 0.66 & 0.75 & 0.85 \\
\hline $\begin{array}{l}\text { Number of citations time weighted } \\
\text { (in logs) in nano }\end{array}$ & 3.59 & 0.98 & 3.44 & 0.91 & 3.74 & 0.92 & 3.60 & 0.93 & 3.46 & 1.18 \\
\hline $\begin{array}{l}\text { Date of the first nanotechnology } \\
\text { publication }\end{array}$ & 1994.67 & 5.68 & 1980.93 & 4.16 & 1989.52 & 1.72 & 1995.93 & 2.32 & 2001.37 & 1.59 \\
\hline Male & 0.80 & 0.40 & 0.91 & 0.29 & 0.89 & 0.32 & 0.78 & 0.41 & 0.72 & 0.45 \\
\hline \multicolumn{11}{|l|}{ Age at the survey date } \\
\hline 30-39 years & 0.13 & 0.18 & 0.00 & 0.00 & 0.00 & 0.00 & 0.08 & 0.12 & 0.44 & 0.56 \\
\hline 40-49 years & 0.45 & 0.50 & 0.03 & 0.17 & 0.20 & 0.40 & 0.59 & 0.49 & 0.43 & 0.50 \\
\hline 50-59 years & 0.27 & 0.45 & 0.30 & 0.47 & 0.53 & 0.50 & 0.25 & 0.43 & 0.08 & 0.27 \\
\hline 60 years and older & 0.15 & 0.36 & 0.67 & 0.48 & 0.27 & 0.45 & 0.08 & 0.27 & 0.05 & 0.23 \\
\hline \multicolumn{11}{|l|}{ Doctoral discipline } \\
\hline Physics & 0.32 & 0.34 & 0.47 & 0.53 & 0.13 & 0.30 & 0.31 & 0.29 & 0.26 & 0.33 \\
\hline Biology & 0.07 & 0.26 & 0.03 & 0.17 & 0.11 & 0.32 & 0.06 & 0.24 & 0.09 & 0.28 \\
\hline Mechatronics & 0.18 & 0.39 & 0.06 & 0.24 & 0.24 & 0.43 & 0.15 & 0.36 & 0.25 & 0.43 \\
\hline Earth science & 0.03 & 0.18 & 0.00 & 0.00 & 0.02 & 0.14 & 0.04 & 0.19 & 0.05 & 0.23 \\
\hline Chemistry & 0.39 & 0.49 & 0.44 & 0.42 & 0.50 & 0.45 & 0.44 & 0.50 & 0.35 & 0.48 \\
\hline Observations & \multicolumn{2}{|c|}{495} & \multicolumn{2}{|c|}{33} & \multicolumn{2}{|c|}{99} & \multicolumn{2}{|c|}{270} & \multicolumn{2}{|c|}{93} \\
\hline
\end{tabular}


Table 2: Professional characteristics after entry in nanotechnology (to be used to explain scientific production)

\begin{tabular}{|c|c|c|c|c|c|c|c|c|c|c|}
\hline & \multicolumn{2}{|c|}{ All sample } & \multicolumn{2}{|c|}{ First movers } & \multicolumn{2}{|c|}{ Second movers } & \multicolumn{2}{|c|}{ Third movers } & \multicolumn{2}{|c|}{ Last movers } \\
\hline Variable* & Mean & $\begin{array}{l}\text { Std. } \\
\text { Dev. }\end{array}$ & Mean & $\begin{array}{l}\text { Std. } \\
\text { Dev. }\end{array}$ & Mean & $\begin{array}{l}\text { Std. } \\
\text { Dev. }\end{array}$ & Mean & $\begin{array}{l}\text { Std. } \\
\text { Dev. }\end{array}$ & Mean & $\begin{array}{l}\text { Std. } \\
\text { Dev. }\end{array}$ \\
\hline $\begin{array}{l}\text { Employed at a public research } \\
\text { institution }\end{array}$ & 0.60 & 0.49 & 0.79 & 0.45 & 0.61 & 0.39 & 0.60 & 0.43 & 0.58 & 0.41 \\
\hline PI for national projects & 0.59 & 0.49 & 0.58 & 0.50 & 0.62 & 0.49 & 0.59 & 0.49 & 0.57 & 0.50 \\
\hline PI for European projects & 0.33 & 0.47 & 0.45 & 0.51 & 0.42 & 0.50 & 0.29 & 0.45 & 0.28 & 0.45 \\
\hline PI for international projects & 0.16 & 0.36 & 0.18 & 0.39 & 0.23 & 0.42 & 0.15 & 0.36 & 0.09 & 0.28 \\
\hline Managing team or laboratory & 0.21 & 0.40 & 0.58 & 0.50 & 0.36 & 0.48 & 0.14 & 0.35 & 0.10 & 0.30 \\
\hline Scientific mobility & 0.52 & 0.45 & 0.47 & 0.50 & 0.55 & 0.50 & 0.61 & 0.49 & 0.63 & 0.48 \\
\hline Co-authorship network size & 123.17 & 79.73 & 156.01 & 120.18 & 149.61 & 95.93 & 119.43 & 68.70 & 95.40 & 64.51 \\
\hline Co-authorship network density & 0.09 & 0.05 & 0.07 & 0.12 & 0.07 & 0.03 & 0.09 & 0.05 & 0.12 & 0.07 \\
\hline Affiliation to a top-5 French site & 0.43 & 0.50 & 0.49 & 0.51 & 0.40 & 0.48 & 0.43 & 0.50 & 0.44 & 0.50 \\
\hline Observations & \multicolumn{2}{|c|}{495} & \multicolumn{2}{|c|}{33} & \multicolumn{2}{|c|}{99} & \multicolumn{2}{|c|}{270} & \multicolumn{2}{|c|}{93} \\
\hline
\end{tabular}

*All variables describe individual characteristics in a period going from the first publication in nanotechnology to the survey date. 
Table 3: Professional characteristics preceding entry in nanotechnology (to be used in the endogeneity equation)

\begin{tabular}{|c|c|c|c|c|c|c|c|c|c|c|}
\hline \multirow[b]{2}{*}{ Variable* } & \multicolumn{2}{|c|}{ All sample } & \multicolumn{2}{|c|}{ First movers } & \multicolumn{2}{|c|}{ Second movers } & \multicolumn{2}{|c|}{ Third movers } & \multicolumn{2}{|c|}{ Last movers } \\
\hline & Mean & Std. Dev. & Mean & $\begin{array}{l}\text { Std. } \\
\text { Dev. }\end{array}$ & Mean & $\begin{array}{l}\text { Std. } \\
\text { Dev. }\end{array}$ & Mean & $\begin{array}{l}\text { Std. } \\
\text { Dev. }\end{array}$ & Mean & Std. Dev. \\
\hline \multicolumn{11}{|l|}{$\begin{array}{r}\text { Age at the date of the first pub. in } \\
\text { nano.: }\end{array}$} \\
\hline 30-39 years & 0.62 & 0.65 & 0.64 & 0.61 & 0.50 & 0.63 & 0.67 & 0.71 & 0.62 & 0.68 \\
\hline 40-49 years & 0.30 & 0.46 & 0.36 & 0.49 & 0.42 & 0.48 & 0.25 & 0.43 & 0.28 & 0.45 \\
\hline $50-59$ years & 0.08 & 0.27 & 0.00 & 0.00 & 0.08 & 0.28 & 0.08 & 0.27 & 0.08 & 0.27 \\
\hline 60 years and older & 0.00 & 0.06 & 0.00 & 0.00 & 0.00 & 0.00 & 0.00 & 0.00 & 0.02 & 0.15 \\
\hline Scientific mobility & 0.27 & 0.24 & 0.16 & 0.12 & 0.19 & 0.14 & 0.29 & 0.22 & 0.33 & 0.28 \\
\hline \multicolumn{11}{|l|}{ Scientific legitimacy : } \\
\hline Number of publications & 10.81 & 22.19 & 3.91 & 4.51 & 11.30 & 17.23 & 11.19 & 23.99 & 11.62 & 24.86 \\
\hline Number of citations & 643.29 & 5643.74 & 176.48 & 476.32 & 379.72 & 901.56 & 433.58 & 1526.59 & 1698.34 & 12722.57 \\
\hline \multicolumn{11}{|l|}{ Collaboration networks: } \\
\hline Co-authorship network size & 9.46 & 15.44 & 4.24 & 4.99 & 8.90 & 10.32 & 10.03 & 17.61 & 10.26 & 15.28 \\
\hline Co-authorship network density & 0.05 & 0.12 & 0.05 & .07 & 0.06 & 0.13 & 0.06 & 0.13 & 0.03 & 0.06 \\
\hline \multicolumn{11}{|l|}{ Access to field-specific resources: } \\
\hline $\begin{array}{l}\text { Number of coauthors on the first } \\
\text { pub. in nano. already active in } \\
\text { nano. }\end{array}$ & 2.15 & 2.04 & 0.80 & 0.85 & 1.26 & 1.37 & 2.13 & 1.93 & 3.38 & 2.40 \\
\hline $\begin{array}{l}\text { Employed at a public research } \\
\text { institution }\end{array}$ & 0.71 & 0.51 & 0.79 & 0.47 & 0.58 & 0.41 & 0.57 & 0.42 & 0.53 & 0.48 \\
\hline $\begin{array}{l}\text { Affiliation to a top- } 5 \text { French site at } \\
\text { the date of first pub. in nano. }\end{array}$ & 0.33 & 0.47 & 0.32 & 0.49 & 0.26 & 0.43 & 0.34 & 0.47 & 0.35 & 0.48 \\
\hline $\begin{array}{l}\text { Affiliation to a non-French } \\
\text { institution at the date of first pub. } \\
\text { in nano. }\end{array}$ & 0.09 & 0.28 & 0.15 & 0.36 & 0.10 & 0.31 & 0.09 & 0.29 & 0.04 & 0.20 \\
\hline Observations & \multicolumn{2}{|c|}{495} & \multicolumn{2}{|c|}{33} & \multicolumn{2}{|c|}{99} & \multicolumn{2}{|c|}{270} & \multicolumn{2}{|c|}{93} \\
\hline
\end{tabular}

* All variables describe individual characteristics before or at the date of the first publication in nanotechnology. 
The descriptive statistics in Table 1 reveal that scientific production varies between 6 and 364 articles, with a mean of 47 . The distribution of this production is asymmetric: a high proportion publishes a few articles, and a few researchers have a very high number of publications, in accordance with Lotka's (1926) law.

\subsection{A preliminary and descriptive approach to first mover advantage}

As shown on figure 2, the average year of the first nanotechnology publication is approximately 1994 and is highly concentrated during the 1990s, which coincides with the emergence of European nanotechnology research (Youtie et al., 2008).

Figure 2: Distribution of the date of the first publication in nanotechnology

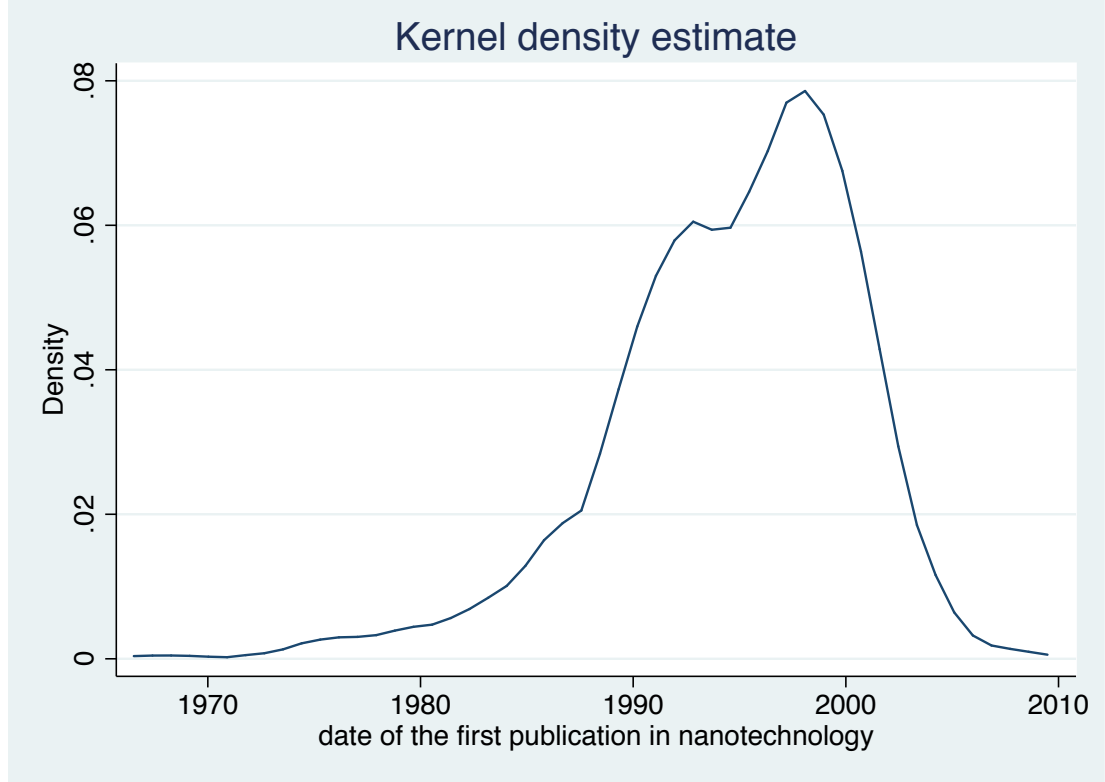

Our data also shows strong differences in production according to the entry rank in nanotechnology publications. We considered four types of scientists, defined according to the date of their first publication, based on three turning points in the history of the field (Palmberg, Dernis, and Miguet 2009): the discovery of Fullerenes (1985), the discovery of Carbone nanotube (1991) and the discovery of dip-pen nanolithography (1999). The third period (1991-1999) corresponds with a dramatic increase in the total number of publications worldwide (Guan and Ma 2007; Li et al., 2008; Miyazaki and Islam, 2007). During the last period (1999-...), new specialty journals burgeoned (Leydesdorff, 2008; Schummer, 2004) and public funding grew dramatically in major countries, following the launch of the US Nano Initiative in 2001 (Badillo, 2012; Wang and Shapira, 2011).

From a descriptive standpoint, our data suggests that first and second movers are more productive (figure 3). However, this finding could result from a temporal bias, in that the production of last movers could be right-censored. To avoid this bias, we weighted scientific production by the number of observation years, i.e. difference between the date of the first publication and 2013 (figure 4). 
Figure 3: Distribution of the number of publications in nanotechnology by entry rank

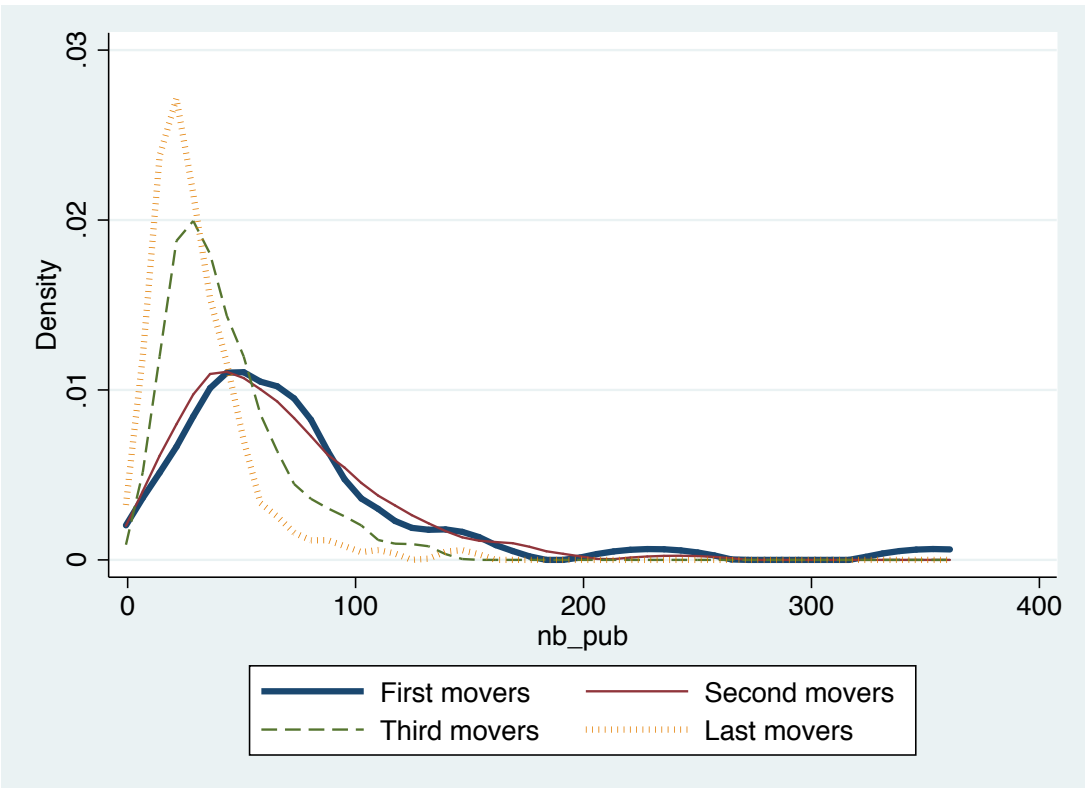

Figure 4: Distribution of the number of publications time weighted in nanotechnology by entry rank

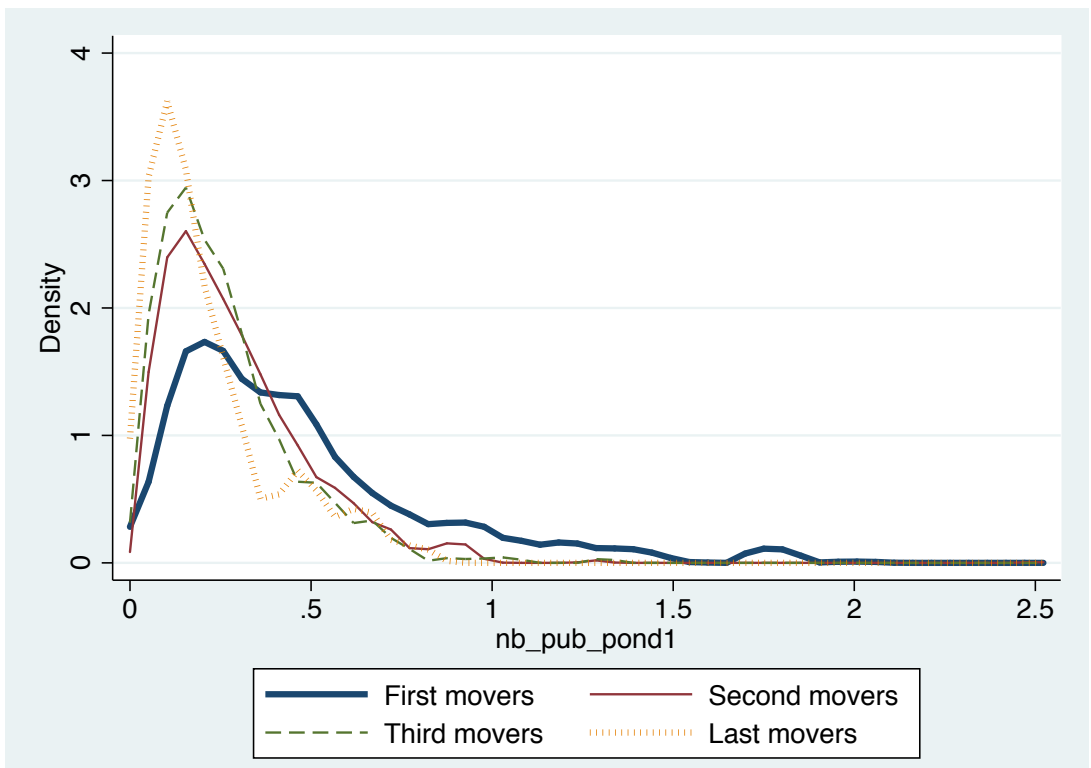

When publication are time weighted, the pattern becomes less evident. The advantage seems to maintain for first-movers but it considerably weakens for second-movers. As there is obviously a risk of arbitrariness in any attempt to break down the development of a field into sub periods, we looked at similar descriptive analyses applied to five other types of 
breakdown ${ }^{4}$. In all of them, the advantage of earliness either considerably weakens or simply vanishes when temporal bias is accounted for, which illustrates the complexity of the link between entry rank and scientific production. Tables 1 and 3 affirm that first movers have specific attributes compared with other researchers; for example, they are more represented among male scientists and physicists. Moreover, their careers preceding their first nanotechnology publication also differ. Before entering the field, first movers had been more mobile. Importantly, pioneers were much more productive before their first nanotechnology publication, regardless of discipline. In addition, first movers were more likely to have worked in public institutions before their first nanotechnology publication, possibly because these institutions have fewer temporal and financial constraints when exploring new scientific fields.

This first descriptive approach suggests that pioneering behavior is probably a selective process, as stressed by Garcia-Villaverde et al. (2012). It also suggests that in order to test the first mover advantage, we must use an adequate estimation methodology, such that we can control for an endogeneity bias. We thus estimated the effect of entry rank on scientific production in nanotechnology using ordinary least squares (model 1), instrumental-variables regressions via generalized method of moments - GMM (model 2a through 2c), which address endogeneity bias. In the instrumental regression (model $2 \mathrm{a}$ ), we analyzed the determinants of the entry timing (i.e. date of first publication in nanotechnology). As instruments, we introduced all variables listed in table 3 . We then analyzed scientific production outputs in nanotechnology (time weighted) comparing two measures: the number of publications (model $2 \mathrm{~b}$ ) and the number of citations (model $2 \mathrm{c}$ ). To test the robustness of our method, we computed two tests. First, a Hausman test was done to test whether the entry date is endogenous or not. Second, a Hansen-Sargan overidentification test (Davidson and MacKinnon, 2004; Baum et al., 2003) ${ }^{5}$ allowed us to test the joint null hypothesis that the instruments are valid, that is uncorrelated with errors and thus the output variables. Last, because models 1 and 2 exploit only the cross-sectional dimension of our data, there is a risk of bias due to unobserved heterogeneity (Baltagi, 2008). For example, the scientists in our sample may have variable abilities such that the more able have a higher chance to succeed in their attempts and, ultimately, to enter the field earlier. We thus analyzed further our data with a panel approach (model 3), using a Hausman-Taylor estimator (Hausman and Taylor, 1981; Amemiya and MaCurdy, 1986). This estimator allows accounting for endogeneity in panel analysis where some of the endogenous variables are time-invariant, which is the case of the date of first nanotechnology publication in our case. For all models, we computed overall system R-square values (Greene, 2012) to measure the prediction quality of our models.

\footnotetext{
4 The turning points in the evolution of the field were identified successively (a) based on a distinct timeline of key discoveries (1981, 1985, 1991, as appears in Miyazaki and Islam 2007), (b) based on the quartiles of the distribution of entry date in our sample $(1991,1992,1997,1999)$, (c) based on the growth of the total number of publication worldwide (1991, 1998, inferred from Arora et al. 2013 and from Palmberg et al., 2009), (d) based on the structure of "publication market shares" among leading nations (1991, 2001, inferred from Guan and Ma 2007) and (e) based on the growth of government funding worldwide (2001, inferred from Palmberg et al., 2009 and from Shapira and Wang 2010).

5 We here computed overidentification tests robust to heteroscedasticy (Hayashi, 2000, pp.227-28).
} 


\section{Results}

Table 4 presents our results. Model 2a reports the instrumental equation, that is, the estimates of the variable suspected to be endogenous, the date of entry, using instruments. Models $2 \mathrm{~b}$ and $2 \mathrm{c}$ reports the estimates of the key outputs (publications and citations after the entry date) once controlling for the endogeneity of the date of entry. A negative coefficient in model 2 a means that the variable increases the odds of entering early in the field (it reduces the date of entry).

The date of the first publication in nanotechnology strongly depends on several attributes, as suggested in the descriptive analysis (section 3.3). The three types of mechanisms described in section 2.2 appear to have an impact: scientific legitimacy, strong collaboration networks and access to field-specific resources do increase the odds of entering the field early. As per scientific legitimacy, the number of publications before field entry favors first mover behaviors. Highly productive researchers hold extensive knowledge of existing theories and their limitations, probably allowing them to identify weak points and innovations to lead. Moreover, their high status may facilitate the acceptance of submitted papers, in a context where the novelty of the field creates intense uncertainty on paper quality (Azoulay et al., 2013).

The influence of prior collaboration networks (as argued in section 2.2.3) is based on both their size and their structure. First, scientists with larger networks have higher chances to enter the field early. As new fields generally develop around a pre-existing structure of collaborators (Perry and Rice 1998), scientists with large personal networks might face lower failure rate when entering the field. As per network structure, we found that density also favors early entry. Whereas sparse networks have been for long argued to favor knowledge circulation (McFadyen et al., 2009; Rost, 2011), our findings seems to support the view that the mutual understanding and trust associated to "closure" (Burt, 2005) is needed when it comes to engaging in projects conveying more risk.

The third type of mechanism, which we identified in section 2.2.4., access to field-specific resources, also provides interesting implications. It was captured, first, through the affiliation to one of the 5 major French sites in nanotechnology (Badillo, 2012) at the date of the first publication in nanotechnology. Scientists in those locations could use unique equipment and tap into a strong knowledge base. It suggests that a great deal of the conditions required for pioneering behavior are out of individual scientists' hands and rely on research policy makers and their efforts to build strong local competences to support individual research strategies. A comparable effect might be at play behind the effect of affiliation to a non-French institution, in a context where several other countries provided more funding and equipment on average than France (most notably the US). Last, similar access to resources can be conveyed by personal relationships instead of affiliation: having collaborators already established in nanotechnology also increases the odds of earliness. 
Table 4: Results

\begin{tabular}{|c|c|c|c|c|c|}
\hline Variables & $\begin{array}{l}\text { Model } 1 \\
\text { OLS }\end{array}$ & $\begin{array}{l}\text { Model 2a } \\
\text { GMM }\end{array}$ & $\begin{array}{l}\text { Model 2b } \\
\text { GMM }\end{array}$ & $\begin{array}{l}\text { Model 2c } \\
\text { GMM }\end{array}$ & $\begin{array}{c}\text { Model } 3 \\
\text { Error- } \\
\text { component } \\
\text { s model } \\
\text { (Hausman- } \\
\text { Taylor } \\
\text { estimator) }\end{array}$ \\
\hline & $\begin{array}{l}\text { Number of } \\
\text { publications } \\
\text { in nano time } \\
\text { weighted (in } \\
\text { logs) }\end{array}$ & $\begin{array}{l}\text { Date of the } \\
\text { first } \\
\text { publication } \\
\text { in nano. }\end{array}$ & $\begin{array}{l}\text { Number of. } \\
\text { publications in } \\
\text { nano. time } \\
\text { weighted (in } \\
\text { logs) }\end{array}$ & $\begin{array}{l}\text { Number of } \\
\text { citations in } \\
\text { nano. field } \\
\text { time } \\
\text { weighted (in } \\
\text { logs) }\end{array}$ & $\begin{array}{l}\text { Number of. } \\
\text { publications }\end{array}$ \\
\hline $\begin{array}{l}\text { Date of the first nanotechnology } \\
\text { publication }\end{array}$ & $\begin{array}{c}-0.145^{* * *} \\
(-2.099) \\
\end{array}$ & & $\begin{array}{l}-0.069 * * \\
(-2.016) \\
\end{array}$ & $\begin{array}{c}-0.243^{* * *} \\
(-3.289)\end{array}$ & $\begin{array}{l}-0.073^{* *} \\
(-2.145) \\
\end{array}$ \\
\hline Male & $\begin{array}{c}0.164^{* * *} \\
(3.946) \\
\end{array}$ & $\begin{array}{c}-1.782^{* * *} \\
(-3.252) \\
\end{array}$ & $\begin{array}{l}0.095^{*} \\
(1.817) \\
\end{array}$ & $\begin{array}{c}0.395^{* *} \\
(2.106) \\
\end{array}$ & $\begin{array}{l}0.092^{*} \\
(1.906) \\
\end{array}$ \\
\hline $\begin{array}{l}\text { Age at the survey date: } 30-39 \\
\text { years }\end{array}$ & Ref. & & Ref. & Ref. & Ref. \\
\hline $\begin{array}{l}\text { Age at the survey date: } 40-49 \\
\text { years }\end{array}$ & $\begin{array}{c}-0.505^{* * *} \\
(-9.004)\end{array}$ & & $\begin{array}{c}-0.502 * * * \\
(-9.086)\end{array}$ & $\begin{array}{c}-0.423 * * * \\
(-5.964)\end{array}$ & $\begin{array}{c}-0.497^{* * *} \\
(-8.805)\end{array}$ \\
\hline $\begin{array}{l}\text { Age at the survey date: 50-59 } \\
\text { years }\end{array}$ & $\begin{array}{l}-0.864 * * * \\
(-12.451) \\
\end{array}$ & & $\begin{array}{l}-0.848 * * * \\
(-13.634) \\
\end{array}$ & $\begin{array}{c}-0.967 * * * \\
(-8.775) \\
\end{array}$ & $\begin{array}{l}-0.856 * * * \\
(-12.867) \\
\end{array}$ \\
\hline $\begin{array}{l}\text { Age at the survey date: } 60 \text { years } \\
\text { and older }\end{array}$ & $\begin{array}{c}-1.221^{* * *} \\
(-13.91)\end{array}$ & & $\begin{array}{l}-1.163^{* * *} \\
(-16.169) \\
\end{array}$ & $\begin{array}{c}-1.067^{* * *} \\
(-12.002)\end{array}$ & $\begin{array}{c}-1.159 * * * \\
(-17.003)\end{array}$ \\
\hline Doctoral discipline: Biology & $\begin{array}{l}-0.096^{*} \\
(-1.640)\end{array}$ & $\begin{array}{l}-0.195^{*} \\
(-1.719)\end{array}$ & $\begin{array}{l}-0.105^{*} \\
(-1.664)\end{array}$ & $\begin{array}{l}-0.156^{*} \\
(-1.785)\end{array}$ & $\begin{array}{l}-0.104^{*} \\
(-1.701)\end{array}$ \\
\hline Doctoral discipline: Mechatronics & $\begin{array}{l}-0.003^{*} \\
(-1.792) \\
\end{array}$ & $\begin{array}{l}-1.040^{*} \\
(-1.834) \\
\end{array}$ & $\begin{array}{l}-0.034^{* *} \\
(-1.678) \\
\end{array}$ & $\begin{array}{l}-0.042^{* *} \\
(-1.699) \\
\end{array}$ & $\begin{array}{l}-0.040^{*} \\
(-1.638) \\
\end{array}$ \\
\hline Doctoral discipline: Earth science & $\begin{array}{l}-0.204^{*} \\
(-1.712)\end{array}$ & $\begin{array}{l}-2.104^{*} \\
(-1.693)\end{array}$ & $\begin{array}{l}-0.138^{*} \\
(-1.667)\end{array}$ & $\begin{array}{l}-0.140^{*} \\
(-1.782)\end{array}$ & $\begin{array}{l}-0.190^{*} \\
(-1.665)\end{array}$ \\
\hline Doctoral discipline: Chemistry & $\begin{array}{l}-0.029 * \\
(-1.718) \\
\end{array}$ & $\begin{array}{l}-0.411^{*} \\
(-1.707) \\
\end{array}$ & $\begin{array}{l}-0.044^{*} \\
(-1.723) \\
\end{array}$ & $\begin{array}{l}-0.056 * \\
(-1.735) \\
\end{array}$ & $\begin{array}{l}-0.039^{*} \\
(-1.707) \\
\end{array}$ \\
\hline Doctoral discipline: Physics & Ref. & & Ref. & Ref. & Ref. \\
\hline $\begin{array}{l}\text { Employed by public research } \\
\text { institution }\end{array}$ & $\begin{array}{l}0.002^{* *} \\
(2.036)\end{array}$ & & $\begin{array}{l}0.017^{* *} \\
(2.038)\end{array}$ & $\begin{array}{l}0.094^{* *} \\
(2.135)\end{array}$ & $\begin{array}{l}0.022^{* *} \\
(2.027)\end{array}$ \\
\hline $\begin{array}{l}\text { Scientific mobility after first } \\
\text { nanotechnology publication }\end{array}$ & $\begin{array}{l}0.004^{* *} \\
(2.035) \\
\end{array}$ & & $\begin{array}{l}0.046^{* *} \\
(2.040) \\
\end{array}$ & $\begin{array}{l}0.078^{* *} \\
(2.103) \\
\end{array}$ & $\begin{array}{l}0.051^{* *} \\
(2.104) \\
\end{array}$ \\
\hline PI for national projects & $\begin{array}{c}0.007^{* * *} \\
(3.037)\end{array}$ & & $\begin{array}{c}0.008^{* * *} \\
(3.037)\end{array}$ & $\begin{array}{c}0.005^{* * *} \\
(2.856)\end{array}$ & $\begin{array}{c}0.010^{* * *} \\
(2.997)\end{array}$ \\
\hline PI for European projects & $\begin{array}{l}0.002^{* *} \\
(2.138)\end{array}$ & & $\begin{array}{l}0.003^{* *} \\
(2.138)\end{array}$ & $\begin{array}{c}0.003 * * \\
(2.009) \\
\end{array}$ & $\begin{array}{l}0.002^{* *} \\
(2.099)\end{array}$ \\
\hline PI for international projects & $\begin{array}{l}0.064^{* *} \\
(2.050) \\
\end{array}$ & & $\begin{array}{l}0.063^{* *} \\
(2.052) \\
\end{array}$ & $\begin{array}{c}0.132 * * * \\
(3.127) \\
\end{array}$ & $\begin{array}{l}0.056^{* *} \\
(1.998) \\
\end{array}$ \\
\hline Managing a laboratory & $\begin{array}{c}-0.093^{* *} \\
(-2.139)\end{array}$ & & $\begin{array}{l}-0.083^{*} \\
(-1.938)\end{array}$ & $\begin{array}{l}-0.383^{*} \\
(-1.907)\end{array}$ & $\begin{array}{l}-0.091 * \\
(-1.923)\end{array}$ \\
\hline Network size (in logs) & $\begin{array}{l}0.852^{* * *} \\
(16.561) \\
\end{array}$ & & $\begin{array}{l}0.024 * * * \\
(12.033) \\
\end{array}$ & $\begin{array}{l}0.156^{* * *} \\
(12.201) \\
\end{array}$ & $\begin{array}{l}0.021^{* * *} \\
(12.059) \\
\end{array}$ \\
\hline Network density & $\begin{array}{c}0.049^{* *} \\
(2.135)\end{array}$ & & $\begin{array}{c}0.026^{* *} \\
(2.164)\end{array}$ & $\begin{array}{c}0.075^{* *} \\
(2.004)\end{array}$ & $\begin{array}{c}0.031^{* *} \\
(2.097)\end{array}$ \\
\hline
\end{tabular}




\begin{tabular}{|c|c|c|c|c|c|}
\hline Affiliation to a top-5 French site & $\begin{array}{r}0.023^{* *} \\
(2.078)\end{array}$ & & $\begin{array}{r}0.024^{* *} \\
(2.067)\end{array}$ & $\begin{array}{l}0.145^{* * *} \\
(2.989)\end{array}$ & $\begin{aligned} 0.045^{* *} \\
(2.006)\end{aligned}$ \\
\hline $\begin{array}{l}\text { Age at the first pub. date: } 30-39 \\
\text { years }\end{array}$ & & Ref. & & & \\
\hline Age at the first pub: $40-49$ years & & $\begin{array}{l}1.394^{* *} \\
(1.999)\end{array}$ & & & \\
\hline Age at the first pub: $50-59$ years & & $\begin{array}{l}3.845^{* *} \\
(2.184) \\
\end{array}$ & & & \\
\hline $\begin{array}{l}\text { Age at the survey date: } 60 \text { years } \\
\text { and older }\end{array}$ & & $\begin{array}{r}4.007^{* *} \\
(2.042)\end{array}$ & & & \\
\hline $\begin{array}{l}\text { Employed at a public research } \\
\text { institution before } \\
\text { first pub. in nano. }\end{array}$ & & $\begin{array}{c}-1.051^{* *} \\
(-3.024)\end{array}$ & & & \\
\hline $\begin{array}{l}\text { Scientific mobility before first pub. } \\
\text { in nano. }\end{array}$ & & $\begin{array}{l}-0.054^{* *} \\
(-2.061)\end{array}$ & & & \\
\hline $\begin{array}{l}\text { Duration between doctoral } \\
\text { completion and first job }\end{array}$ & & $\begin{array}{r}-0.003 * * \\
(-2.056)\end{array}$ & & & \\
\hline \multicolumn{6}{|l|}{ Scientific legitimacy } \\
\hline $\begin{array}{l}\text { Number of publications before first } \\
\text { pub. in nano. (in logs) }\end{array}$ & & $\begin{array}{c}-0.077^{* * *} \\
(-3.063)\end{array}$ & & & \\
\hline $\begin{array}{l}\text { Number of citations before first } \\
\text { pub. in nano. (in logs) }\end{array}$ & & $\begin{array}{c}-0.004 * * * \\
(-3.598)\end{array}$ & & & \\
\hline \multicolumn{6}{|l|}{ Collaboration networks: } \\
\hline $\begin{array}{l}\text { Co-autorship network size before } \\
\text { first pub. in nano. (in logs) }\end{array}$ & & $\begin{array}{c}-0.107^{* * *} \\
(-2.152)\end{array}$ & & & \\
\hline $\begin{array}{l}\text { Co-autorship network density } \\
\text { before first pub. in nano. }\end{array}$ & & $\begin{array}{r}-1.294^{* *} \\
(-2.065) \\
\end{array}$ & & & \\
\hline \multicolumn{6}{|l|}{ Access to field-specific resources: } \\
\hline $\begin{array}{l}\text { Number of co-authors on first pub. } \\
\text { already active in } \\
\text { nano. (in logs) }\end{array}$ & & $\begin{array}{c}-0.119 * * \\
(-2.187)\end{array}$ & & & \\
\hline $\begin{array}{l}\text { Affiliation to a top- } 5 \text { site at the } \\
\text { date of first pub. in nano. }\end{array}$ & & $\begin{array}{l}-0.412^{* *} \\
(-2.199)\end{array}$ & & & \\
\hline $\begin{array}{l}\text { Affiliation to a non-French } \\
\text { institution at the date of the first } \\
\text { pub. in nano. }\end{array}$ & & $\begin{array}{r}-1.841^{* *} \\
(-1.982)\end{array}$ & & & \\
\hline Constant & $\begin{array}{c}18.171^{* * *} \\
(8.379)\end{array}$ & $\begin{array}{c}1.996 * * * \\
(2.714) \\
\end{array}$ & $\begin{array}{c}79.809 * * * \\
(13.631) \\
\end{array}$ & $\begin{array}{c}45.035^{* * *} \\
(11.856) \\
\end{array}$ & $\begin{array}{c}71.248^{* * *} \\
(14.067) \\
\end{array}$ \\
\hline Observations & 495 & 495 & 495 & 495 & 23683 \\
\hline R-squared & 0.729 & 0.590 & 0.730 & 0.780 & \\
\hline Hausman test & & & 2.899 & 3.006 & \\
\hline Hansen-Sargan test value & & & $\begin{array}{c}5.670 \\
\text { (p-value: } 0.187) \\
\end{array}$ & $\begin{array}{c}4.876 \\
\text { (p-value: } \\
0.212 \text { ) } \\
\end{array}$ & $\begin{array}{c}5.775 \\
\text { (p-value: } \\
0.161 \text { ) } \\
\end{array}$ \\
\hline Sigma_u & & & & & 0.963 \\
\hline Sigma_e & & & & & 0.178 \\
\hline Rho & & & & & 0.919 \\
\hline
\end{tabular}

NB : Robust student $t$ appear in parentheses. ${ }^{* * *}$ : significant at $1 \%,{ }^{* *}$ : significant at $5 \%,{ }^{*}$ : significant at $10 \%$ 
Other variables also favor early entry. Men and physicists are overrepresented among first movers. The most mobile researchers also are more likely to be pioneers. Last, our results indicate that working for a public institution seems to encourage pioneering behavior. Public institutions are funded by the government and have no short-term profitability target. Therefore, they are typically less reluctant to engage in long-term research projects whose outcomes are uncertain and sunk costs are high. They also allow more freedom to researchers in defining their research fields, unlike private laboratories, which suffer more from the market pressure. Thus, the type of institution appears to play an important role in building an incentive environment for pioneers, in accordance with the findings of the Economics of Science (Stephan, 1996). This point deserves to be developed to clarify which other institutional characteristics may encourage or facilitate pioneering behavior. This would require richer data than we have and probably a more qualitative analysis.

All these results clearly show that the entry date depends on several attributes. The Hausman test confirms the endogeneity of this variable. Moreover, the Hansen and Sargan overidentification test indicates that instruments are valid (i.e. explain the entry date but not the key scientific outputs). Our models are thus well identified.

Taking into account the endogeneity of the first mover status, our estimates on crosssectional also show that the earlier the date of the researcher's first nanotechnology publication, the higher his or her scientific production in nanotechnology. If the first publication comes a year earlier, it increases global production by $7.1 \%$ (exp(.069) in terms of the number of publications per year (model $2 b)$ and by $27.5 \%(\exp (.243))$ the number of citations (model $2 \mathrm{c}$ ). This advantage would be greatly overestimated $(+15.6 \%$ year production [model 1] against in reality $7.1 \%$ [model $2 \mathrm{~b}$ ]) if we treated first mover behavior as an exogenous variable.

To test whether this first mover advantage is constant over time, we estimated, using the same method as in model 2, the effect of the date of entry on publications five years after this date, between five and ten years afterwards and more than ten years after. Table 5 gives a summary of the results, focusing on the key variables ${ }^{6}$.

Table 5: Impact of the entry date on publications over time

\begin{tabular}{|l|c|c|c|c|}
\hline $\begin{array}{l}\text { Number of nanotechnology } \\
\text { publications time weighted (in } \\
\text { logs) }\end{array}$ & All publications & $\begin{array}{c}\text { Publications 5 } \\
\text { years after the } \\
\text { date of the first } \\
\text { pub. }\end{array}$ & $\begin{array}{c}\text { Publications } \\
\text { between } 6 \text { and } \\
10 \text { years after } \\
\text { the date of the } \\
\text { first pub. }\end{array}$ & $\begin{array}{c}\text { Publications } \\
\text { more than } 10 \\
\text { years after the } \\
\text { date of the first } \\
\text { pub. }\end{array}$ \\
\hline $\begin{array}{l}\text { Date of the first } \\
\text { nanotechnology publication }\end{array}$ & $-0.069 * *$ & $-0.063 * *$ & $-0.067 * * *$ & $-0.072 * * *$ \\
& $(-2.016)$ & $(-2.164)$ & $(-3.213)$ & $(-3.567)$ \\
\hline
\end{tabular}

Results suggest that the first mover advantage is relatively constant over time.

The approach described in models $2 a$ through $2 c$ has the strong advantage of shedding light on the factors affecting entry timing. However, it fails to take into account the unobserved

\footnotetext{
6 Detailed results are available upon request.
} 
individual heterogeneity, such as abilities, which could affect scientific production. Thus, we also analyzed our data with a panel specification approach, using a Hausman-Taylor estimator (model 3). The similarity in findings across approaches (cross-sectional and longitudinal), provides stronger evidence that pioneers do hold an advantage.

This result supports Price's (1965) and Newman's (2009) conclusions and suggests that the positive effects of being a first mover outweigh the potential negative effects (as discussed in Section 2.1). Researchers in nanotechnology (and their laboratories) seem to erect informal and formal barriers to entry more easily than in other economic sectors can. First, reputational effects appear more important in the research sector. They help create virtuous circles in which the most reputable researchers capture more resources and are placed on the most productive trajectories (Merton, 1968). This effect, widely documented in prior literature, may explain why pioneers are more likely to capitalize on their findings. Second, focusing on the research sector, the nanotechnology field's characteristics are more favorable to the existence of a first mover advantage. More than in other disciplines, the high cost of nanotechnology equipment confers a benefit to researchers who are well funded before entering the field. This advantage contributes to creating economies of scales and experience effects that can limit the success of later entrants.

\section{Discussion and conclusion}

This article analyses whether first movers in research have a sustainable competitive advantage in publications. Literature points to both positive and negative effects of pioneering research. Moreover, entry timing seems to be a strategic and then endogenous variable. Finally, though the first mover effect has been largely studied in marketing and management science, no consensus has emerged regarding the existence of a first mover advantage in research. Using an original database that combines bibliometric data and a survey of French nanotechnology scientists, we thus analyze (1) whether the pioneer status is endogenous and (2) the impact of being a first mover on future production.

Our main results are two-fold. First, pioneering behavior in research is endogenous. Researchers that are already established in their "mother discipline", who have strong (large and dense) collaboration networks, and who have access to field-specific resources through their affiliation or collaboration ties, are more likely to enter early an emerging field. Mobility as well as working in public institutions also increase the odds. Second, being a pioneer leads to a strong advantage in the scientific production path, even more notably when citations are taken into account. This finding provides clear indications for the management of scientific research. Promoting ground-breaking, innovative research provides an important advantage for future scientific production. Laboratories should encourage emerging research, which is more risky but also more profitable. Our results confirm Arthur's (1998) claim that "two maxims are widely accepted in knowledge based markets: it pays to hit the market first and it pays to have superb technology". Laboratories also can boost their chances of developing innovative research by recruiting high-performing researchers, who are already recognized in the field and have strong collaboration networks.

Further investigations may refine these results. First, it would be worthwhile to study all research projects, including those that have failed. In this article, we focused only on 
successful, published studies. However, in the discovery phase, the failure rate is high and affects more pioneers. By focusing on publications, we may have overestimated the first mover advantage. A qualitative and longitudinal approach comparing successful with unsuccessful projects could address this limitation and makes an interesting research avenue.

Second, this study takes into account the role of institutions, emphasizing the important role of public laboratories as well as specific local contexts to favor pioneering behaviors. Future work could complement this analysis by further characterizing this context (i.e. organization size, budget, team composition). Doing so would more accurately reflect the collective nature of research, as highlighted by Stephan (1996). Besides, that context might either hamper or facilitate pioneering behavior raises further questions on the nature of such behavior, which our data is too limited to settle. In particular, to what extent is entering a new field a truly deliberate decision? And if it is, how does it form? How does the will of scientists to enter a field interacts with the specificities of their local constraints and resources to affect their chances of success? Future research should investigate the process of decision-making behind entry timing. For this purpose, one could borrow from the vast body of entrepreneurship research focusing on the formation of intention to start a business and how it translates into action (Shook et al., 2003; Van Gelderen et al., 2015). The latter shows that intention and action emerge from a complex interaction between individual and environmental characteristics.

Third, though the nanotechnology field is well suited to the analysis of pioneering behavior, it is also fairly specific, especially in light of the equipment involved. Moreover, the delineation of fields raises challenge to our research question, that further work should address. Most importantly, how do fields emerge "within fields"? As nanotechnology research became stronger and stronger, subfields emerged overtime, and progressively structured themselves into specific and independent communities. This somehow challenges our approach: some second-movers in nanotechnology could be considered as first-movers in, say nanomedicine. For example the discovery of Graphene by Geim and Novoselov, which eventually won them the Nobel prize, occurred in 2004, which is relatively "late" by the standards used in this paper ${ }^{7}$. Yet, this breakthrough opened new prospects and attracted a population of researchers to work specifically on Graphene, with virtually similar mechanisms of first mover advantage.

Fourth, our study was limited to the French context. To what extent are our findings applicable to other countries is unclear. For the sake of exploring this aspect, we conducted additional descriptive analyses (available upon request) similar to those conducted in section 3.4, on all nanotechnology publications in the USA and in Germany: from a strictly descriptive standpoint, we found comparable patterns of a first mover advantage. However, one contribution of our study is to show that this descriptive approach is insufficient: entry time is endogenous and the study of the first mover advantage needs to rely on instrument variables which necessarily require fine-grained information on individual characteristics. Both the factors of entry timing and the ability to translate earliness in success could vary across countries. For example, in other systems, such as the American system, institutions

\footnotetext{
${ }^{7}$ We thank one anonymous reviewer for pointing specifically this example.
} 
have more freedom to decide upon their research strategy and therefore can more freely put a priority on an emerging field. Funding is another factor which varies importantly across countries (Shapira and Wang, 2010) and certainly affect the occurrence and success of pioneering behavior. It would be interesting to see future research applying our integrative approach to other countries than France.

\section{References}

Amemiya T., MaCurdy T.E.., 1986. Instrumental-variable estimation of an error-components model. Econometrica, 54, 869-880.

Arora S. K., Porter A. L., Youtie J., Shapira P., 2013. Capturing new developments in an emerging technology: an updated search strategy for identifying nanotechnology research outputs. Scientometrics, 95, 1, 351370.

Arthur W.B., 1998. Increasing returns and the new world of business. Harvard Business Review 74, 4, $100-110$.

Avenel E., Favier A.V., Ma S., Mangematin V., Rieu C., 2007. Diversification and hybridization in firm knowledge bases in nanotechnologies. Research Policy 36, 6, 864-870.

Azoulay, P., Stuart, T., Wang, Y., 2013. Matthew: Effect or fable? Management Science 60, 1, 92-109.

Badillo P.-Y., 2012. Les nanotechnologies : un nouveau paradigme. Les cahiers de I'ANR, 5, Agence Nationale de la Recherche.

Baltagi B., 2008, Econometric analysis of panel data. John Wiley \& Sons.

Baum C.F., Schaffer M.E., Stillman S., 2003. Instrumental Variables and GMM: Estimation and Testing. Stata Journal, 3, 1-31.

Beaudry C., Allaoui S., 2012. Impact of public and private research funding on scientific production: The case of nanotechnology. Research Policy, 419, 1589-1606.

Bonaccorsi, A., 2008. Search regimes and the industrial dynamics of science. Minerva 46, 3, 285-315.

Bonaccorsi A., Daraio C., 2003. Age effects in scientific productivity. The case of the Italian national research council (CNR). Scientometrics 58, 1, 47-88.

Boulding W., Christen M., 2008. Disentangling pioneering cost advantages and disadvantages. Marketing Science 27, 4, 699-716.

Bozeman B., Larédo P., Mangematin V., 2007. Understanding the emergence and deployment of "nano" S\&T. Research Policy, 36, 6, 807-812.

Braben D.W., 2004. Pioneering Research: A Risk Worth Taking. Hoboken NJ: Wiley Interscience.

Burt R. S., 2005. Brokerage and Closure: An Introduction to Social Capital. New-York: Oxford University Press.

Carpenter G.S., Nakamoto K., 1989. Consumer preference formation and pioneering advantage. Journal of Marketing Research 26, 3, 285-298.

Clark B. R., 1993. The Research Foundations of Graduate Education: Germany, Britain, France, United States, Japan. Univ of California Press.

Darby M., Zucker L., 2005. Grilichesian breakthroughs: Inventions of methods of inventing and firm entry in nanotechnology. Annales d'Economie et de Statistiques 79-80, 143-164.

Davidson R., MacKinnon J., 2004. Econometric Theory and Methods. New York: Oxford University Press.

Debackere K., Rappa M.A., 1993. An international comparison of scientists in an emerging field. International Journal of Technology Management 8, 6-8, 740-763.

Debackere K., Rappa M.A., 1994. Institutional variations in problem choice and persistence among scientists in an emerging field. Research Policy 23, 4, 425-441.

Diamond A.M., 1986. The life-cycle research productivity of mathematicians and scientists. The Journal of Gerontology 41, 520-525.

Franco A.M., Sarkar M.B., Agarwal R., Echambadi R., 2009. Swift and smart: The moderating effects of technological capabilities on the market pioneering-firm survival relationship. Management Science 55, 11, 1842-1860.

Gal-Or E., 1985. First and second mover advantages. International Economic Review 26, 649-653.

Gal-Or E., 1987. First mover disadvantages with private information. Review of Economic Studies 54, $279-292$.

García-Villaverde P.M., Ruiz-Ortega M.J., Parra-Requena G. 2012. Towards a comprehensive model of entry timing in the ICT industry: Direct and indirect effects. Journal of World Business 47, 2, 297-310

Gans J.S., Shepherd G.B. 1994. How are the mighty fallen: Rejected classic articles by leading economists. The Journal of Economic Perspectives 8, 1, 165-179. 
Gomez-Villanueva J.E., Ramírez-Solís E.R., 2013. Is there a real pioneer's advantage? Lessons learned after almost thirty years of research. Academy of Strategic Management Journal 12, 2, 31-53.

Greene W., 2012. Econometric Analysis. Prentice Hall.

Griliches Z., 1957. Hybrid corn: An exploration in the economics of technological change. Econometrica 25, 501522.

Guan J., Ma N., 2007. China's emerging presence in nanoscience and nanotechnology: A comparative bibliometric study of several nanoscience "giants." Research Policy, 36, 6, 880-886.

Hausman J.A., Taylor W.E., 1981. Panel data and unobservable individual effects. Econometrica, 49, 1377-1398.

Hayashi F., 2000. Econometrics. Princeton: Princeton University Press.

Higgins M.J., Stephan P.E., Thursby J.G., 2011. Conveying quality and value in emerging industries: Star scientists and the role of signals in biotechnology. Research Policy 40, 4, 605-617.

Huang C., Notten A., Rasters N., 2011. Nanoscience and technology publications and patents: a review of social science studies and search strategies. The Journal of Technology Transfer 36, 2, 145-172.

Hunter L., Leahey E., 2010. Parenting and research productivity: New evidence and methods. Social Studies of Science 40, 3, 433-451.

Jensen R., 2003. Innovative leadership: First mover advantages in new product adoption. Economic Theory 21 , $1,97$.

Jonkers K., Cruz-Castro L., 2013. Research upon return: The effect of international mobility on scientific ties, production and impact. Research Policy 42, 8, 1366-1377.

Kerin R.A., Varadarajan P.R., Peterson R.A., 1992. First mover advantage: A synthesis, conceptual framework and research propositions. Journal of Marketing 56, 33-52.

Kim J.W., 2012. Arbiter of science: Institutionalization and status effects in FDA drug review 1990-2004. Strategic Organization 10, 2, 128-157.

Kim J.W., King B.G., 2014. Seeing stars: Matthew effects and status bias in Major League Baseball umpiring. Management Science, 60, 11, 2619-2644.

Kuhn T.S., 1962 (reedited in 1970). The Structure of Scientific Revolutions. University of Chicago Press, Chicago.

Laudan L., 1977. Progress and Its Problems: Towards a Theory of Scientific Growth. University of California Press, Berkeley CA.

Laudel G., 2002. What do we measure by co-authorships?. Research Evaluation 11, 1, 3-15.

Lee C., Sugimoto C., Zhang G., Cronin B., 2013. Bias in peer review. Journal of the American Society for Information Science \& Technology 64, 1, 2-17.

Lee G.K., 2008. Relevance of organizational capabilities and its dynamics: What to learn from entrants' product portfolios about the determinants of entry timing. Strategic Management Journal 29, 12, 1257-1280.

Leydesdorff L., 2008. The delineation of nanoscience and nanotechnology in terms of journals and patents: $A$ most recent update. Scientometrics, 76, 1, 159-167.

Li X., Chen H., Dang Y., Lin Y., Larson C.A., Roco, M.C., 2008. A longitudinal analysis of nanotechnology literature: 1976-2004. Journal of Nanoparticle Research, 10, 1, 3-22.

Lieberman M.B., Montgomery D.B., 1988. First mover advantages. Strategic Management Journal 9, 41-58.

Lilien G.L., Yoon E., 1990. The timing of competitive market entry: An exploratory study of new industrial products. Management Science 36, 5, 568-585.

Lotka A.J., 1926. The frequency distribution of scientific productivity. Journal of the Washington Academy of Sciences 16, 512, 317-323.

Luukkonen T., 2012. Conservatism and risk-taking in peer review: Emerging ERC practices. Research Evaluation 21, 1, 48-60.

McFadyen M.A., Semadeni M., Cannella J.A.A., 2009. Value of Strong Ties to Disconnected Others: Examining Knowledge Creation in Biomedicine. Organization Science, 20,3, 552-564.

Merton R.K., 1968. The Matthew effect. Science 159, 3810, 56-63

Metzger N., Zare R.N., 1999. Interdisciplinary research: From belief to reality. Science 283, 5402, 642-643.

Mody C.C., 2011. Instrumental Community: Probe Microscopy and the Path to Nanotechnology. MIT Press, Cambridge.

Mogoutov A., Kahane B., 2007. Data search strategy for science and technology emergence: A scalable and evolutionary query for nanotechnology tracking. Research Policy 36, 893-903.

Moore M. J., Boulding, W., Goodstein R. C., 1991. Pioneering and market share: is entry time endogenous and does it matter?. Journal of Marketing Research 28, 1, 97-104.

Miyazaki K., Islam N., 2007. Nanotechnology systems of innovation-An analysis of industry and academia research activities. Technovation, 27,11, 661-675.

Newman M.E.J., 2009. The first mover advantage in scientific publication. Europhysics Letters 86, 6, 68001. 
Palmberg C., Dernis H., Miguet C, 2009, Nanotechnology: An Overview based on Indicators and Statistics, OECD STI Working Paper, 7, 112p.

Perry C.A., Rice R.E., 1998. Scholarly communication in developmental dyslexia: Influence of network structure on change in a hybrid problem area. Journal of the American Society for Information Science 49, 2, 151-168.

Pezzoni M., Sterzi V., Lissoni F., 2012. Career progress in centralized academic systems: Social capital and institutions in France and Italy. Research Policy 41, 4, 704-719.

Porter A.L., Rossini F.A., 1985. Forty interdisciplinary research projects: Multiple skills and peer review. Managing High Technology: An Interdisciplinary Perspective. B. W. Mar, W. T. Newell, and B. O. Saxberg, 103-112. Elsevier, New York.

Podolny J.M., Stuart T. E., Hannan M.T., 1996. Networks, knowledge, and niches: Competition in the worldwide semiconductor industry, 1984-1991. American Journal of Sociology 659-689.

Price D.J. de S., 1965. Networks of scientific papers. Science 149, 510-515.

Reagans, R., McEvily B., 2003. Network Structure and Knowledge Transfer: The Effects of Cohesion and Range. Administrative Science Quarterly, 48, 2, 240-267.

Robinson D. K., Rip A., Mangematin V., 2007. Technological agglomeration and the emergence of clusters and networks in nanotechnology. Research policy, 36, 6, 871-879.

Rocco M., Bainbridge W.S., 2002. Converging technologies for improving human performance in nanotechnology, biotechnology, information technology and cognitive science. NSF, Arlington, Virginia.

Rost K., 2011. The strength of strong ties in the creation of innovation. Research Policy 40, 4, 588-604.

Shapira P., Wang J., 2010, Follow the money. Nature, 468, 7324, 627-628.

Schummer J., 2004. Multidisciplinarity, interdisciplinarity, and patterns of research collaboration in nanoscience and nanotechnology. Scientometrics, 59, 3, 425-465.

Shook C.L., Priem R.L., McGee J.E., 2003. Venture creation and the enterprising individual: A review and synthesis. Journal of Management, 29, 3, 379-399.

Stephan P.E., 1996. The economics of science. Journal of Economic Literature 34, 3, 1199-1235.

Stephan P.E., Levin S.G., 1997. The critical importance of careers in collaborative scientific research. Revue d'Economie Industrielle 79, 45-61.

Suarez F.F., Gianvito L., 2007. The role of environmental dynamics in building a first mover advantage theory. Academy of Management Review 32, 2, 377-392.

Van Gelderen M., Kautonen T., Fink M., 2015. From entrepreneurial intentions to actions: Self-control and action-related doubt, fear, and aversion. Journal of Business Venturing. 30, 5, 655-673.

Van Raan A.F., 2004. Sleeping beauties in science. Scientometrics 59, 3, 467-472.

Wally S., Fong C., 2000. Effects of firm performance, organizational slack and debt on entry timing: A study of ten emerging product markets in USA. Industry \& Innovation 7, 2, 169-183.

Wang J., Shapira P., 2011. Funding acknowledgement analysis: an enhanced tool to investigate research sponsorship impacts: the case of nanotechnology. Scientometrics, 87, 3, 563-586.

Whitley R., 2003. Competition and pluralism in the public sciences: the impact of institutional frameworks on the organisation of academic science. Research Policy, 32, 6, 1015-1029.

Youtie J., Shapira P., Porter A.L., 2008. Nanotechnology publications and citations by leading countries and blocs. Journal of Nanoparticle Research 10, 6, 981-986.

Zucker L.G., Darby M.R., Furner J., Liu R.C., Ma H., 2007. Minerva unbound: Knowledge stocks, knowledge flows and new knowledge production. Research Policy 36, 6, 850-863.

Zuckerman H., 1978. Theory choice and problem choice in science. Sociological Inquiry 48, 3-4, 65-95.

\section{Acknowledgements}

This research received support from Agence Nationale de la Recherche (Hybridtrajectories - ANR Blanc $\left.n^{\circ} 1811-01\right)$. We are thankful to Jojo Jacob, Severine Louvel and Vincent Mangematin for invaluable feedback. We also thank Annelise Fondary and Lionel Villard for their help during data collection. 